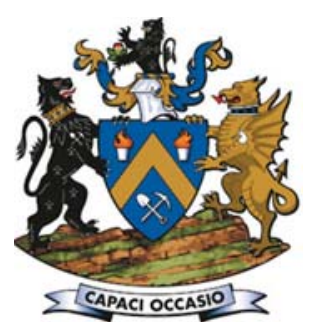

\title{
Control of complex inclusions in high- strength ship plate steel by reducing calcium treatment
}

\author{
by S. Zhao*, F-L. Zhang ${ }^{\dagger}$, L. Ma*, T. Yan*, J-C. Lv*, and \\ S-P. $\mathbf{H e}^{\ddagger}$
}

\section{Synopsis}

To eliminate nozzle clogging during continuous casting of ship plate steel and reduce the calcium addition required, the composition of $\mathrm{CaO}-\mathrm{MgO}$ $\mathrm{Al}_{2} \mathrm{O}_{3}$ inclusions in the liquid phase region must be controlled.

Thermodynamic calculations using FactSage show that when the balanced $\mathrm{Al}$ content is 0.03 mass $\%, a_{\mathrm{Ca}}$ in the liquid steel is $1-10 \mathrm{ppm}$, and $a_{\mathrm{Mg}}$ is $0.01-0.3 \mathrm{ppm}$; and when the balanced Al content is 0.06 mass $\%, a_{\mathrm{Ca}}$ in the liquid steel is $1-30 \mathrm{ppm}$, and $a_{\mathrm{Mg}}$ is $0.05-0.9 \mathrm{ppm}$. The $\mathrm{CaO}-\mathrm{Al}_{2} \mathrm{O}_{3}-\mathrm{CaS}$ inclusions can be controlled in the liquid region below $1600^{\circ} \mathrm{C}$ at $a_{\mathrm{Ca}}$ values of $5 \mathrm{ppm}, 15 \mathrm{ppm}$, and $30 \mathrm{ppm}$, and the balanced $\mathrm{Al}$ content should be controlled in the range of $0.001-0.050,0.005-0.250$, and $0.010-0.50$ mass $\%$, respectively. Based on theoretical analysis, the refining slag composition should be controlled to $45-53$ mass $\% \mathrm{CaO}, 30-37$ mass $\%$ $\mathrm{Al}_{2} \mathrm{O}_{3}, 6-12$ mass $\% \mathrm{SiO}_{2}$, and 6-8 mass \% MgO. Optimization of the slag system and steel composition can reduce, or even eliminate, the requirement for calcium treatment. The total oxygen content in the slab can be controlled to $15-21 \mathrm{ppm}$, with typical micro-inclusions $\leq 10 \mu \mathrm{m}$ in size, with compositions in the $\mathrm{CaO}-\mathrm{Al}_{2} \mathrm{O}_{3}-\mathrm{MgO}$ and $\mathrm{CaO}-\mathrm{Al}_{2} \mathrm{O}_{3}-\mathrm{CaS}$ systems.

\section{Keywords}

calcium treatment, refining slag, inclusions, ship plate steel, melting point.

\section{Introduction}

With the rapid growth in steel output in China and the changes in the macroeconomic environment, competition in the steel industry has become more intense. The technology for economical cleaning of high-grade steel is important for improving product quality and reducing production costs. However, the functions of refining equipment have not been fully taken into consideration, and the combination of refining methods has not been optimized completely. These problems have become a bottleneck, restricting modern steel enterprises from developing an economic clean steel production process. Ship plate steel produced by the converter long process has been selected as the example in this study. The composition of the steel is shown in Table I. This steel is a high-strength low-alloy steel for rolling media and heavy plates, mainly used for ocean-going vessels and other steel structures. The carbon content in the steel is far from the peritectic point, and the crack sensitivity of the slab surface is weak, so impurities and gas content are strictly limited.
Therefore, the process route BOF (basic oxygen furnace) - LF (ladle furnace) - CC (continuous casting) needs to be studied.

The $\mathrm{Al}_{2} \mathrm{O}_{3}$ deoxidation products in ship plate steel are extremely hard, with angular geometries, and resist deformation due to having a melting point above processing temperatures. As such, it is inevitable that scabs and cracks are formed during the casting process, and significant complications arise as a result of adherence to the submerged entry nozzle (SEN) inner wall during casting, which can cause blocking of the SEN. Such inclusions also could damage the steel surface during cold rolling (Zhang, Aoki, and Thomas, 2006' Joo, 2007; Xu, 2009). Thus, the process cannot meet the hot charging requirements and the compact layout demand for continuous casting and rolling. At present, the most commonly used method to reduce the impact of these complications is to change the $\mathrm{Al}_{2} \mathrm{O}_{3}$ inclusions in the molten steel into calcium aluminate by feeding $\mathrm{Ca}$ within the ladle (Kaushik, Lehmann, and Nadi, 2012; Pretorius, Oltmann, and Cash, 2009; Wang, Li, and Wang, 2009; Zhao et al., 2013). In addition, manipulation of the molten steel is sometimes performed to change the distribution of inclusions in order to avoid the inclusions adhering to the SEN inner wall; a side effect of which is to homogenize the microstructure of the billet, resulting in improved steel quality. However, the calcium efficiency is very low and the content is difficult to control accurately during the feeding process. This increases the production cost and the possibility of secondary oxidation (Geldenhuis and Pistorius, 2000; Coletti et al.,

* College of Materials Science and Engineering, Hebei University of Engineering, China.

+ Hebei Research Institute of Iron and Steel Technology, China.

₹ College of Materials Science and Engineering, Chongqing University, China.

(C) The Southern African Institute of Mining and Metallurgy, 2019. ISSN 2225-6253. Paper received May 2017; revised paper received Apr. 2018. 
Table I

Chemical compositions of target steel, mass $\%$

\begin{tabular}{|l|c|c|c|c|c|c|c|c|c|}
\hline & $\mathbf{C}$ & $\mathbf{S i}$ & $\mathbf{M n}$ & $\mathbf{P}$ & $\mathbf{S}$ & $\mathbf{A l t}$ & $\mathbf{N b}$ & $\mathbf{N i}$ & $\mathbf{V}$ \\
\hline $\begin{array}{l}\text { Control range } \\
\text { Target }\end{array}$ & $\begin{array}{c}0.11-0.16 \\
0.14\end{array}$ & $\begin{array}{c}0.10-0.50 \\
0.30\end{array}$ & $\begin{array}{c}1.00-1.60 \\
1.35\end{array}$ & $\begin{array}{c}\leq 0.025 \\
\leq 0.020\end{array}$ & $\begin{array}{c}\leq 0.020 \\
\leq 0.012\end{array}$ & $\begin{array}{c}0.020-0.070 \\
0.030\end{array}$ & $\leq 0.009$ & $\leq 0.30$ & $\leq 0.03$ \\
\end{tabular}

2003; Fuhr, Cicutti, and Walter, 2003; Holappa, Liukkonen, and Lind, 2003). For operations producing thousands of tons of steel per annum, the reduction or elimination of calcium treatment can greatly reduce the operating costs.

In response to the above problems, this investigation was carried out to optimize the Ca feeding process in the manufacturing of ship plate steel, as well as the equilibrium reaction of different refining slag systems, to obtain a reasonable calcium content in the molten steel and refining slag composition. We have developed the most advantageous method of controlling the inclusion morphology, reducing the total oxygen and impurity content in the steel, and laying the foundation for the economic processing of ship plate steel via the steps converter tapping, ladle furnace, reduced or no calcium treatment, and slab casting.

\section{Thermodynamic analysis of the reaction between inclusions and liquid steel}

Typical inclusion compositions can be controlled in the low melting-point area by manipulating the $\mathrm{Ca}, \mathrm{Al}, \mathrm{Mg}$, and $\mathrm{O}$ contents of the molten steel. Because the high-strength ship plate steel belongs to the class of high-Al and low-Ti steels $[\mathrm{Al}]=0.015-0.070$ mass \%, $[\mathrm{Ti}]=0.010-0.020$ mass $\%$, the deoxidation products are mainly $\mathrm{Al}_{2} \mathrm{O}_{3}$ inclusions in the stable region. Only if the Ti content is higher than $0.1 \%$ will a $\mathrm{Al}_{2} \mathrm{O}_{3} \cdot \mathrm{TiO}_{2}$ phase be formed. As a result, this paper mainly focuses on the modification and removal of the $\mathrm{Al}_{2} \mathrm{O}_{3}$ inclusions in steel.

\section{Equilibrium calculation of $\mathrm{Al}_{2} \mathrm{O}_{3}-\mathrm{MgO}$ inclusions and liquid steel}

$\mathrm{MgO} \cdot \mathrm{Al}_{2} \mathrm{O}_{3}$ spinel inclusions are often found in steel that has been treated by aluminum deoxidation. The thermodynamic conditions for $\mathrm{MgO} \cdot \mathrm{Al}_{2} \mathrm{O}_{3}$ spinel inclusions and their formation were calculated using FactSage software.

The $\mathrm{MgO}-\mathrm{Al}_{2} \mathrm{O}_{3}$ phase diagram calculated using the FactSage software is shown in Figure 1. The $\mathrm{MgO}$ content is less than 30 mass \% in the $\mathrm{MgO} \cdot \mathrm{Al}_{2} \mathrm{O}_{3}$ spinel zone.

$\mathrm{MgO} \cdot \mathrm{Al}_{2} \mathrm{O}_{3}$ is very hard and has a melting point of $2135^{\circ} \mathrm{C}$. It undergoes no deformation in the hot rolling process, which reduces the anti-fatigue properties of the steel and, greatly decreases the steel quality.

When $\mathrm{Mg}$ is present in the molten steel, there are two possible reactions by which $\mathrm{MgO} \cdot \mathrm{Al}_{2} \mathrm{O}_{3}$ inclusions can form. The $\mathrm{Mg}$ and dissolved $\mathrm{O}$ can react, forming $\mathrm{MgO}$ directly in the steel, then $\mathrm{MgO}$ and $\mathrm{Al}_{2} \mathrm{O}_{3}$ combine to form spinel inclusions; alternatively, the dissolved $\mathrm{Mg}$ may react directly with the $\mathrm{Al}_{2} \mathrm{O}_{3}$ inclusions present in the steel (Seo et al., 2003; Yang, Yamasaki, and Kuwabara, 2007; Yang et al., 2011). To calculate the phase boundary between $\mathrm{MgO}$ and $\mathrm{MgO} \cdot \mathrm{Al}_{2} \mathrm{O}_{3}$, Equation [1] is used (Todoroki and Mizuno, 2004).

$$
\begin{aligned}
& 2 \mathrm{Al}+4 \mathrm{MgO}_{(\mathrm{s})}=\mathrm{MgO} \cdot \mathrm{Al}_{2} \mathrm{O}_{3(\mathrm{~s})}+3 \mathrm{Mg} \\
& \log K_{\mathrm{Al}-\mathrm{Mg}}=-33.09+\frac{50880}{\mathrm{~T}}
\end{aligned}
$$

Similarly, to calculate the phase boundary between $\mathrm{MgO} \cdot \mathrm{Al}_{2} \mathrm{O}_{3}$ and $\mathrm{Al}_{2} \mathrm{O}_{3}$, Equation [2] is used (Todoroki and Mizuno, 2004).

$$
\begin{aligned}
& 2 \mathrm{Al}+3 \mathrm{MgO} \cdot \mathrm{Al}_{2} \mathrm{O}_{3(\mathrm{~s})}=4 \mathrm{Al}_{2} \mathrm{O}_{3(\mathrm{~s})}+3 \mathrm{Mg} \\
& \log K_{{\mathrm{MgO} \cdot \mathrm{Al}_{2} \mathrm{O}_{3}}}=-34.37+\frac{46950}{\mathrm{~T}}
\end{aligned}
$$

In the calculation, $\mathrm{MgO}$ and magnesia spinel grains were considered to exist in the pure solid standard state at $1600^{\circ} \mathrm{C}$, and the activities were taken as $a_{\mathrm{MgO}}=1$ and $a_{\mathrm{MgO} \cdot \mathrm{Al}_{2} \mathrm{O}_{3}}=1$ separately. Then, the $\mathrm{Mg}$ - $\mathrm{Al}$ balance relationship can be found when $f_{[\mathrm{Al}]}=1.03$ is brought into Equations [1] and [2] (the activity coefficient of $\mathrm{Mg}$ is greatly influenced by the 0 content, and many interaction coefficients are unknown between the $\mathrm{Mg}$ in molten steel and other dissolved elements, so the $\mathrm{Mg}$ activity coefficient calculation is not entirely accurate; due to the lack of thermodynamic data, and this is only a brief discussion). Using FactSage, the $\mathrm{Mg}$ - $\mathrm{Al}-\mathrm{O}$ system stability diagram is drawn (Figure 2).

According to Figure 2, the stability regions for $\mathrm{MgO}$, $\mathrm{Al}_{2} \mathrm{O}_{3}$, and $\mathrm{MgO} \cdot \mathrm{Al}_{2} \mathrm{O}_{3}$ can be found corresponding to different $\mathrm{Al}$ and $\mathrm{Mg}$ contents in the liquid steel, and the $\mathrm{O}$ content is in calculated equilibrium with the $\mathrm{Al}$ and $\mathrm{Mg}$ contents (see curves in Figure 2). At $1600^{\circ} \mathrm{C}$, as long as the $\mathrm{Mg}$ and $\mathrm{Al}$ contents are very low, there is a high possibility of generating $\mathrm{MgO} \cdot \mathrm{Al}_{2} \mathrm{O}_{3}$. When $[\mathrm{Al}]=0.02-0.06$ mass $\%$ and $[\mathrm{Mg}]=0.5-10 \mathrm{ppm}, \mathrm{MgO} \cdot \mathrm{Al}_{2} \mathrm{O}_{3}$ can be generated, thereby avoiding the formation of $\mathrm{Al}_{2} \mathrm{O}_{3}$. When $[\mathrm{Mg}]>10 \mathrm{ppm}$, it can form MgO. It can be concluded that if there is only a small amount of $\mathrm{Mg}$ in the liquid steel, the formation of $\mathrm{Al}_{2} \mathrm{O}_{3}$ and the spinel precipitate or $\mathrm{MgO}$ will be avoided. Therefore, by

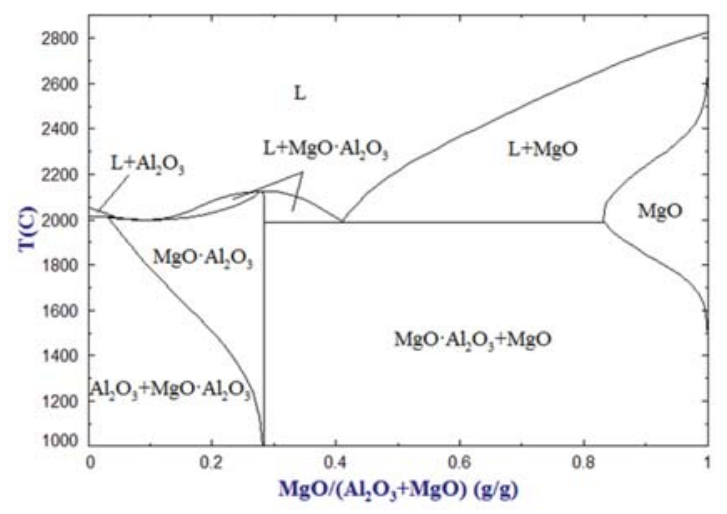

Figure $1-\mathrm{MgO}_{-}-\mathrm{Al}_{2} \mathrm{O}_{3}$ phase diagram 


\section{Control of complex inclusions in high-strength ship plate steel by reducing calcium treatment}

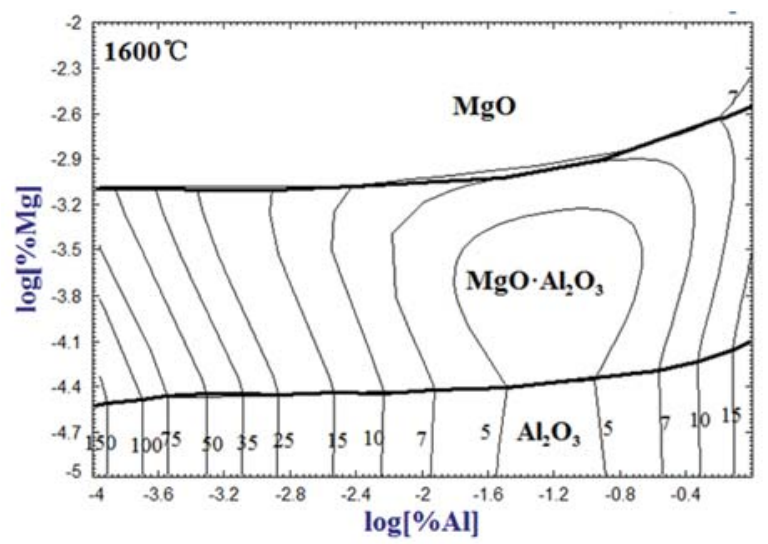

Figure 2-Relationship between $\mathrm{Mg}, \mathrm{Al}$, and inclusions in the steel at $1600^{\circ} \mathrm{C}$

changing the slagging or deoxidation mode, and controlling the contents of dissolved $\mathrm{Mg}, \mathrm{Al}$, and $\mathrm{Ca}$ in the steel, $\mathrm{MgO} \cdot \mathrm{Al}_{2} \mathrm{O}_{3}$ will possibly be converted to another low-melting product.

\section{Equilibrium calculation of $\mathrm{CaO}-\mathrm{Al}_{2} \mathrm{O}_{3}-\mathrm{MgO}$ inclusions and liquid steel}

Spinel inclusions are high melting-point inclusions with a dispersed distribution in the steel. They will cause nozzle clogging and affect the steel quality. The effects of $\mathrm{Al}_{2} \mathrm{O}_{3}$ inclusions, however, are less serious. There have been very few studies on precipitation thermodynamics in the $\mathrm{Fe}-\mathrm{Mg}$ $\mathrm{Ca}-\mathrm{Al}-\mathrm{O}-\mathrm{S}$ system. Therefore, the phase diagrams of the $\mathrm{CaO}$ $\mathrm{Al}_{2} \mathrm{O}_{3}-\mathrm{MgO}$ and $\mathrm{CaO}-\mathrm{Al}_{2} \mathrm{O}_{3}-\mathrm{CaS}$ systems were calculated. By controlling the $\mathrm{Al}, \mathrm{Ca}, \mathrm{Mg}, \mathrm{O}$, and $\mathrm{S}$ contents in molten steel, the inclusions can be restricted to the low melting-point area. Then, the conditions that generate $\mathrm{CaO}-\mathrm{Al}_{2} \mathrm{O}_{3}-\mathrm{MgO}$ inclusions in the low-alloy steel were calculated when the $\mathrm{Al}$ content was taken as between 0.03 mass $\%$ and 0.06 mass $\%$.

In order to calculate the equilibrium relationship between liquid steel and inclusions, first, the activity of each substance in the $\mathrm{CaO}-\mathrm{Al}_{2} \mathrm{O}_{3}-\mathrm{MgO}$ system was calculated at $1600^{\circ} \mathrm{C}$, using FactSage. To control the $\mathrm{CaO}-\mathrm{Al}_{2} \mathrm{O}_{3}-\mathrm{MgO}$ system inclusions in the $1600^{\circ} \mathrm{C}$ liquid zone, the activities of $\mathrm{Al}_{2} \mathrm{O}_{3}, \mathrm{CaO}$, and $\mathrm{MgO}$ need to be controlled separately in the ranges of $0.01-0.25,0.1-0.9$, and $0.01-0.9$ respectively.
In addition to Equations [1] and [2], there are also the following equilibrium reactions between the liquid steel and inclusions in the $\mathrm{CaO}-\mathrm{Al}_{2} \mathrm{O}_{3}-\mathrm{MgO}$ system (Chen, 1984).

$$
\begin{aligned}
& \mathrm{Mg}+\mathrm{O}=(\mathrm{MgO})_{(\mathrm{s})} \Delta G_{\mathrm{MgO}}^{\theta}= \\
& -732952+240.28 \mathrm{~T} \mathrm{~J} \cdot \mathrm{mol}^{-1} \\
& 2 \mathrm{Al}+3 \mathrm{O}=\left(\mathrm{Al}_{2} \mathrm{O}_{3}\right)_{(\mathrm{s})} \Delta G_{\mathrm{Al}_{2} \mathrm{O}_{3}}^{\theta}= \\
& -1202000+386.3 \mathrm{~T} \mathrm{~J} \cdot \mathrm{mol}^{-1} \\
& \mathrm{Ca}+\mathrm{O}=(\mathrm{CaO})_{(\mathrm{s})} \Delta G_{\mathrm{CaO}}^{\theta}= \\
& -491216.28+146.47 \mathrm{~T} \mathrm{~J} \cdot \mathrm{mol}^{-1}
\end{aligned}
$$

The following can be obtained from Equations [3], [4], and [5]:

$$
\begin{aligned}
& 2 \mathrm{Al}+3(\mathrm{MgO})_{(\mathrm{s})}=3 \mathrm{Mg}+\left(\mathrm{Al}_{2} \mathrm{O}_{3}\right)_{(\mathrm{s})} \\
& \Delta G_{\mathrm{Al}-\mathrm{Mg}}^{\theta}=996856-334.54 \mathrm{~T} \mathrm{~J} \cdot \mathrm{mol}^{-1} \\
& 2 \mathrm{Al}+3(\mathrm{CaO})_{(\mathrm{s})}=3 \mathrm{Ca}+\left(\mathrm{Al}_{2} \mathrm{O}_{3}\right)_{(\mathrm{s})} \\
& \Delta G_{\mathrm{Al}-\mathrm{Ca}}^{\theta}=271648.84-53.11 \mathrm{~T} \mathrm{~J} \cdot \mathrm{mol}^{-1}
\end{aligned}
$$

For high-strength ship plate steel, the inclusions should be controlled in the $1600^{\circ} \mathrm{C}$ liquid region when $\mathrm{Al}=0.03$ mass $\%$ and 0.06 mass $\%$ in molten steel. The demand of the $\mathrm{Ca}$ and $\mathrm{Mg}$ contents is shown in Figure 3. A number of $\mathrm{Ca}$ and $\mathrm{Mg}$ iso-activity curves were drawn in FactSage, as shown in Figure $3 a$ and $3 b$, respectively.

It can be seen from Figure 3 that to control the inclusion component range in the $1600^{\circ} \mathrm{C}$ liquid region, when $\mathrm{Al}=$ $0.03 \%, a_{[\mathrm{Ca}]}$ should be controlled to $1-10 \mathrm{ppm}$, and $a_{[\mathrm{Mg}]}$ to 0.01-0.3 ppm. The lower equilibrium Ca requirement in steel can effectively reduce the amount of Si-Ca cored wire fed during secondary refining.

It can be surmised from Figure 4 that when $\mathrm{Al}=0.06$ mass $\%$, to control the inclusions in the $1600^{\circ} \mathrm{C}$ low meltingpoint region, $a_{\mathrm{Ca}}$ should be controlled to $1-30 \mathrm{ppm}$, and $a_{\mathrm{Mg}}$ should be controlled to $0.05-0.9 \mathrm{ppm}$. Through comparative analysis, it is also known that in order to ensure inclusions in the low melting-point region, $a_{\mathrm{Mg}}$ and $a_{\mathrm{Ca}}$ must gradually increase when the $\mathrm{Al}$ content in liquid steel increases from 0.03 mass $\%$ to 0.06 mass $\%$, and the corresponding range of activity is also expanded.
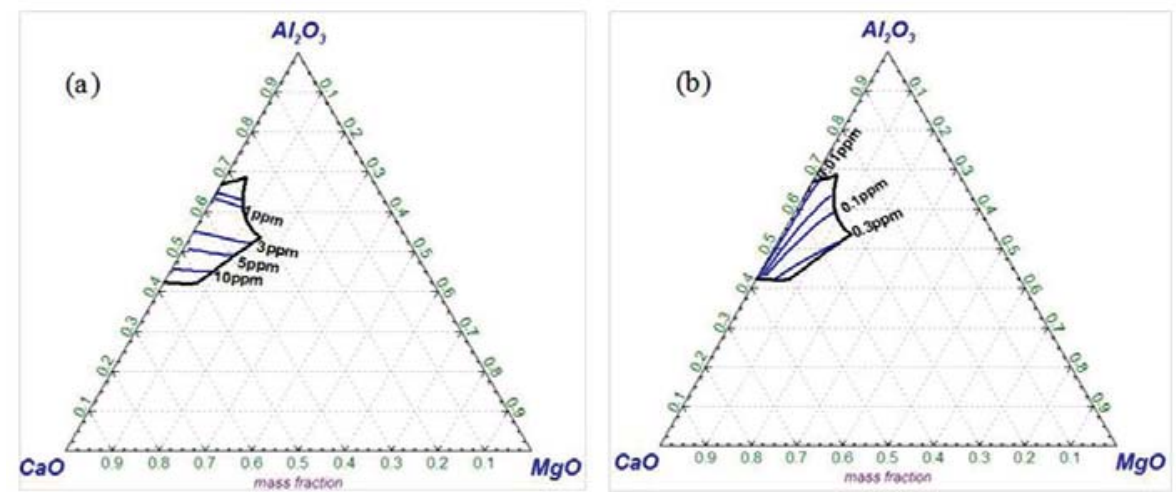

Figure 3-Iso-activity curves of the $\mathrm{CaO}-\mathrm{Al}_{2} \mathrm{O}_{3}-\mathrm{MgO}$ ternary system at $\mathrm{Al}=0.03$ mass $\%, 1600^{\circ} \mathrm{C}$. (a) Iso- $\mathrm{a}_{[\mathrm{Ca}]} \mathrm{curves},(\mathrm{b})$ iso-a $\left.\mathrm{Mg}\right] \mathrm{Curves}$ 


\section{Control of complex inclusions in high-strength ship plate steel by reducing calcium treatment}
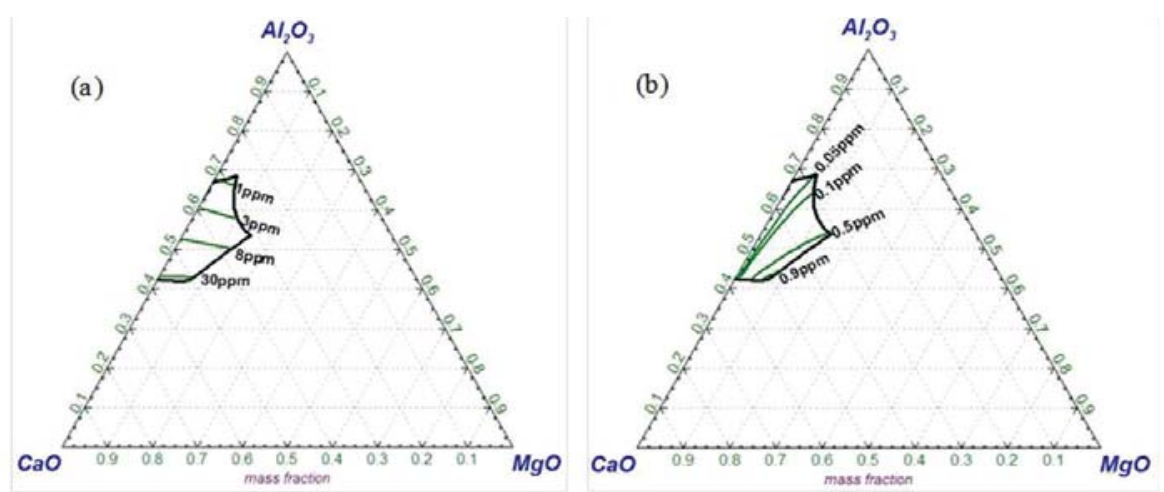

Figure 4-Iso-activity curves of the $\mathrm{CaO}_{-} \mathrm{Al}_{2} \mathrm{O}_{3}-\mathrm{MgO}$ ternary system at $\mathrm{Al}=0.06$ mass $\%, 1600^{\circ} \mathrm{C}$ (a) Iso-a $\mathrm{C}$ a] curves, (b) so-a $[\mathrm{Mg}]$ curves
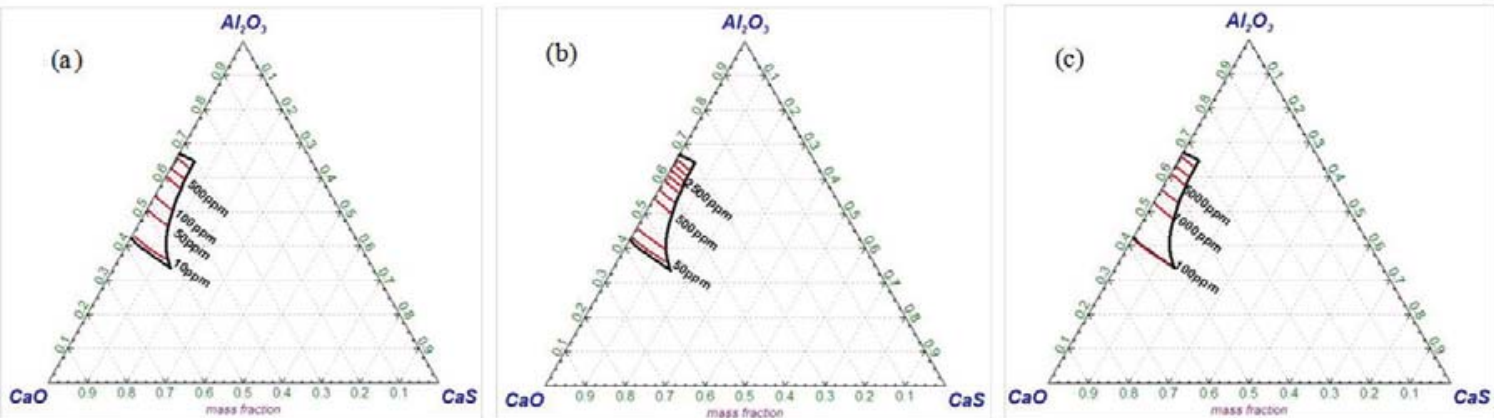

Figure 5-Iso-Al curves of the $\mathrm{CaO}-\mathrm{Al}_{2} \mathrm{O}_{3}-\mathrm{CaS}$ ternary system at different $\mathrm{Ca}$ activities, $1600^{\circ} \mathrm{C}$ (a) $a_{[\mathrm{Ca}]}=5 \mathrm{ppm},(\mathrm{b}) \mathrm{a}_{[\mathrm{Ca}]}=15 \mathrm{ppm},(\mathrm{c}) \mathrm{a}_{[\mathrm{Ca}]}=30 \mathrm{ppm}$

Additionally, according to the Al-Mg-O equilibrium thermodynamic calculation, at $1600^{\circ} \mathrm{C}$, the $\mathrm{Al}$ content increases from 0.02 mass \% to 0.06 mass $\%$ when the $\mathrm{Mg}$ content is in the range of $0.510 \mathrm{ppm}$, and $\mathrm{MgO} \cdot \mathrm{Al}_{2} \mathrm{O}_{3}$ spinel inclusions will be able to form; and the $a_{\mathrm{Mg}}$ needed to control the $\mathrm{CaO}-\mathrm{MgO}-\mathrm{Al}_{2} \mathrm{O}_{3}$ system inclusions in the liquid region is much lower, only 0.01-0.9 ppm. That is, only the lower $\mathrm{Mg}$ content is required in the presence of the liquid steel for generating the $\mathrm{CaO}-\mathrm{MgO}-\mathrm{Al}_{2} \mathrm{O}_{3}$ system composite inclusions, but a certain amount of calcium is required. It can be assumed that as the $\mathrm{Mg}$ content of the liquid steel increases, $\mathrm{MgO} \cdot \mathrm{Al}_{2} \mathrm{O}_{3}$ spinel inclusions are generated first, and then $\mathrm{CaO}-\mathrm{MgO}-\mathrm{Al}_{2} \mathrm{O}_{3}$ inclusions.

\section{Equilibrium calculation of $\mathrm{CaO}-\mathrm{Al}_{2} \mathrm{O}_{3}-\mathrm{CaS}$ inclusions and liquid steel}

The iso-activity diagrams of $\mathrm{Al}_{2} \mathrm{O}_{3}, \mathrm{CaO}$ and $\mathrm{MgO}$ in the $\mathrm{CaO}$ $\mathrm{Al}_{2} \mathrm{O}_{3}$ - $\mathrm{CaS}$ ternary inclusions at $1600^{\circ} \mathrm{C}$ were calculated by FactSage. It can be seen from Figure 5 that in order to control the $\mathrm{CaO}-\mathrm{Al}_{2} \mathrm{O}_{3}-\mathrm{CaS}$ inclusions in the liquid region at $1600^{\circ} \mathrm{C}$, the activities of $\mathrm{Al}_{2} \mathrm{O}_{3}, \mathrm{CaO}$, and $\mathrm{CaS}$ should be controlled to 0.01 in $0.25,0.1$ in 0.9 , and 0.1 in 0.9. In addition to Equation [7], there is also the following reaction (Equation [8]) between the molten steel and inclusions in the CaO$\mathrm{Al}_{2} \mathrm{O}_{3}-\mathrm{CaS}$ system.

$$
\begin{aligned}
& \mathrm{Ca}+\mathrm{S}=(\mathrm{CaS}) \operatorname{lgK} \mathrm{CaS}_{\mathrm{Ca}}= \\
& \lg \left(\frac{\mathrm{a}_{(\mathrm{CaS})}}{\mathrm{a}_{[\mathrm{Ca}]} \cdot \mathrm{a}_{[\mathrm{S}]}}\right)=\frac{19980}{\mathrm{~T}}-5.9
\end{aligned}
$$

At $1600^{\circ} \mathrm{C}$, several iso-Al curves should be drawn by FactSage when $a_{\mathrm{Ca}}=5 \mathrm{ppm}, 15 \mathrm{ppm}$, and $30 \mathrm{ppm}$ in steel, corresponding to the inclusions located in the low meltingpoint region, as shown in Figure 5.

It can be seen from Figures $5 \mathrm{a} \mathrm{c}$ that to control the compositional range of the inclusions in the low meltingpoint area, when $a_{\mathrm{Ca}}$ is $5 \mathrm{ppm}, 15 \mathrm{ppm}$, and $30 \mathrm{ppm}$ the $\mathrm{Al}$ content should be controlled in the range of 0.0010 to 0.050 , 0.0050 to 0.250 , and 0.010 to 0.50 mass $\%$, respectively. Clearly, the $a_{\mathrm{Ca}}$ activity in the target steel can be controlled at $515 \mathrm{ppm}$. As $a_{\mathrm{Ca}}$ is increased, the Al content in liquid steel should be increased gradually for controlling the liquid inclusions.

\section{Characterization of precipitated inclusions}

The theoretical liquidus temperature of the target steel is about $1515^{\circ} \mathrm{C}$. The temperature at the nozzle is generally $20^{\circ} \mathrm{C}$ higher than the liquidus temperature. In the casting process, in order to avoid a large number of precipitated inclusions adhering to the inner wall of the nozzle as the temperature decreases, it is necessary to consider the types and amounts of inclusions precipitated and their influence on the castability when the temperature of the molten steel is reduced from $1600^{\circ} \mathrm{C}$ to the liquid line.

Because refining slag floats and is separated from molten steel at the end of soft-blowing, remaining on the top of the ladle to form top slag, the mass transfer and equilibrium reaction between the molten steel and the top slag can be ignored from a thermodynamic point of view, leaving the main balance between the inclusions in the steel and the steel components to be considered. With decreasing temperature of the molten steel, the dissolved O, S, and alloy elements will reach supersaturation again, thereby generating the inclusions. 


\section{Control of complex inclusions in high-strength ship plate steel by reducing calcium treatment}

Under the internally controlled components of molten steel after refining and interaction coefficients of the metal elements in the molten steel at $1600^{\circ} \mathrm{C}$, the activities of various elements were calculated by FactSage. The $\mathrm{Ca}$ and $\mathrm{O}$ activities in molten steel cannot be measured accurately in situ. They should be calculated according to the balance relationship in Equations [9] and [10]. The results are shown in Table II.

$$
\begin{aligned}
& 2 \mathrm{Al}+3 \mathrm{O}=\left(\mathrm{Al}_{2} \mathrm{O}_{3}\right) \Delta G_{\mathrm{Al}_{2} \mathrm{O}_{3}}^{\theta}= \\
& -1205090+387.73 \mathrm{~T} \mathrm{~J} \cdot \mathrm{mol}^{-1} \\
& \mathrm{Ca}+\mathrm{O}=(\mathrm{CaO}) \Delta G_{\mathrm{CaO}}^{\theta}= \\
& -641300+149.26 \mathrm{~T} \mathrm{~J} \cdot \mathrm{mol}^{-1}
\end{aligned}
$$

The $\Delta G$ of each reaction at $1600^{\circ} \mathrm{C}$ was first calculated from the relevant thermodynamic data (Table III). According to the Gibbs free energy minimum principle, the first inclusions generated are CaS. After reaching the reaction balance between $\mathrm{Ca}$ and $\mathrm{S}$, the $\mathrm{Ca}$ content in the molten steel is very low, and therefore no calcium precipitates will be formed during casting and cooling. Because large quantities of $\mathrm{MnS}$ are formed during the final solidification process, they will not be considered here. Therefore, the elements in the steel are mainly $\mathrm{C}, \mathrm{Si}, \mathrm{Mn}, \mathrm{Al}$, and $\mathrm{O}$.

As the temperature continues to decrease, the equilibrium of the various reactions is broken and the inclusions continue to generate. The possible types of oxide inclusions generated in the molten steel and the associated reaction Gibbs free energies $\left(\Delta G^{\theta}\right)$ are shown in Table IV. Calculated from the related data, $\mathrm{Al}_{2} \mathrm{O}_{3}$ inclusions begin to be generated when the molten steel temperature decreases from $1600^{\circ} \mathrm{C}$ to $1527^{\circ} \mathrm{C}$. When the temperature falls to the liquidus temperature $\left(1515^{\circ} \mathrm{C}\right), \mathrm{Al}_{2} \mathrm{O}_{3}$ precipitates. Because the $\mathrm{Al}_{2} \mathrm{O}_{3}$ Gibbs free energy is the minimum negative value, only the reaction $2 / 3 \mathrm{Al}+\mathrm{O} \rightarrow 1 / 3 \mathrm{Al}_{2} \mathrm{O}_{3}$ is considered.

According to the activity value of each element at $1535^{\circ} \mathrm{C}$ and $1515^{\circ} \mathrm{C}$ in Table $\mathrm{V}$, the $\Delta G$ of $\mathrm{Al}_{2} \mathrm{O}_{3}$ formation has always been smaller than the $\Delta \mathrm{G}$ values for other inclusions, which indicates that when the $2 / 3 \mathrm{Al}+\mathrm{O} \rightarrow 1 / 3 \mathrm{Al}_{2} \mathrm{O}_{3}$ reaction reaches equilibrium, the reactions forming the other inclusions are already balanced, and $\mathrm{Al}_{2} \mathrm{O}_{3}$ inclusions are the primary precipitate in the molten steel during the cooling process. Without taking into consideration the secondary

\begin{tabular}{|c|c|c|c|c|c|c|c|}
\hline Element (i) & $\mathrm{Si}$ & Mn & $S$ & Al & $\mathrm{Ti}$ & $\mathrm{Ca}$ & 0 \\
\hline $\begin{array}{l}f_{i} \\
a_{i}\end{array}$ & $\begin{array}{l}1.165 \\
0.349\end{array}$ & $\begin{array}{l}0.976 \\
1.317\end{array}$ & $\begin{array}{l}0.998 \\
0.018\end{array}$ & $\begin{array}{l}1.038 \\
0.0311\end{array}$ & $\begin{array}{l}1.058 \\
0.016\end{array}$ & $2.9 \times 10^{-7}$ & $1.27 \times 10^{-4}$ \\
\hline
\end{tabular}
oxygenation of the molten steel, no $\mathrm{Al}_{2} \mathrm{O}_{3}$ inclusions

Table II

Activities and activity coefficients of various elements in steel

Table III

Gibbs free energies for the formation of inclusions $(\Delta \mathrm{G}<0), 1600^{\circ} \mathrm{C}$

\begin{tabular}{|c|c|c|c|c|c|}
\hline \multirow[t]{2}{*}{ Type of inclusion } & \multirow[t]{2}{*}{ Reaction } & \multicolumn{4}{|c|}{$\Delta G / n_{[o]}, \mathrm{J} \cdot \mathrm{mol}^{-1}$} \\
\hline & & $1600^{\circ} \mathrm{C}$ & $1535^{\circ} \mathrm{C}$ & $1527^{\circ} \mathrm{C}$ & $1515^{\circ} \mathrm{C}$ \\
\hline $\mathrm{Al}_{2} \mathrm{O}_{3}$ & $2 \mathrm{Al}+3 \mathrm{O} \rightarrow \mathrm{Al}_{2} \mathrm{O}_{3}$ & 16112.9 & 1613.4 & -171.2 & -2848.0 \\
\hline $\mathrm{MnO}$ & $\mathrm{Mn}+\mathrm{O} \rightarrow \mathrm{MnO}$ & 83550.5 & 70438.2 & 68824.4 & 66403.7 \\
\hline $\mathrm{SiO}_{2}$ & $\mathrm{Si}+2 \mathrm{O} \rightarrow \mathrm{SiO}_{2}$ & 64627.7 & 52311.3 & 50795.4 & 48521.6 \\
\hline $\mathrm{MnO} \cdot \mathrm{Al}_{2} \mathrm{O}_{3}$ & $\mathrm{Mn}+2 \mathrm{Al}+4 \mathrm{O} \rightarrow \mathrm{MnO} \cdot \mathrm{Al}_{2} \mathrm{O}_{3}$ & 24365.5 & 10094.2 & 8337.7 & 5703.0 \\
\hline $2 \mathrm{MnO} \mathrm{SiO}_{2}$ & $2 \mathrm{Mn}+\mathrm{Si}+4 \mathrm{O} \rightarrow 2 \mathrm{MnO} \cdot \mathrm{SiO}_{2}$ & 72268.9 & 59152.7 & 57538.4 & 55117.0 \\
\hline $\mathrm{MnO} \cdot \mathrm{SiO}_{2}$ & $\mathrm{Mn}+3 \mathrm{O}+\mathrm{Si} \rightarrow \mathrm{MnO} \cdot \mathrm{SiO}_{2}$ & 63325.1 & 50683.6 & 49127.7 & 46793.9 \\
\hline $3 \mathrm{Al}_{2} \mathrm{O}_{3} \cdot 2 \mathrm{SiO}_{2}$ & $6 \mathrm{Al}+2 \mathrm{Si}+13 \mathrm{O} \rightarrow 3 \mathrm{Al}_{2} \mathrm{O}_{3} \cdot 2 \mathrm{SiO}_{2}$ & 27870.6 & 14129.9 & 12438.7 & 9901.9 \\
\hline $3 \mathrm{MnO} \cdot \mathrm{Al}_{2} \mathrm{O}_{3} \cdot 3 \mathrm{SiO}_{2}$ & $\begin{array}{c}3 \mathrm{Mn}+2 \mathrm{Al}+3 \mathrm{Si}+12 \mathrm{O} \rightarrow \\
3 \mathrm{MnO} \cdot \mathrm{Al}_{2} \mathrm{O}_{3} \cdot 3 \mathrm{SiO}_{2}\end{array}$ & 48235.9 & 35175.2 & 33567.7 & 31156.5 \\
\hline
\end{tabular}

\begin{tabular}{|l|c|c|}
\hline Type of inclusion & Reaction & Gibbs free energy $\Delta G$, J.mol-1 \\
\hline $\mathrm{CaS}$ & $\mathrm{Ca}+\mathrm{S} \rightarrow \mathrm{CaS}$ & -1866.94 \\
$3 \mathrm{CaO} \cdot 2 \mathrm{TiO}_{2}$ & $2 \mathrm{Ti}+7 \mathrm{O}+3 \mathrm{Ca} \rightarrow 3 \mathrm{CaO} \cdot 2 \mathrm{TiO}_{2}$ & -749.60 \\
\hline
\end{tabular}

Table IV

Gibbs free energy $(\Delta G)$ of deoxidation reactions at different temperatures 


\section{Control of complex inclusions in high-strength ship plate steel by reducing calcium treatment}

Table $V$

Activities of elements in steel

\begin{tabular}{|l|c|c|c|c|}
\hline Temp. & $a_{[\mathrm{Si}]}$ & $a_{[\mathrm{Mn}]}$ & $a_{[\mathrm{Al}]}$ & $a_{[\mathrm{O}]}$ \\
\hline $1535^{\circ} \mathrm{C}$ & 0.349 & 1.317 & 0.031 & 0.00005 \\
$1515^{\circ} \mathrm{C}$ & 0.349 & 1.317 & 0.031 & 0.000037 \\
\hline
\end{tabular}

precipitate during cooling from $1600^{\circ} \mathrm{C}$ to the nozzle temperature $\left(1535^{\circ} \mathrm{C}\right)$. The amounts of $\mathrm{Al}_{2} \mathrm{O}_{3}$ precipitated are $19.1 \mathrm{mg}$ per $10 \mathrm{~kg}$ of molten steel, when the temperature is reduced from $1600^{\circ} \mathrm{C}$ to the liquidus temperature $\left(1515^{\circ} \mathrm{C}\right)$.

The above analysis indicates that thermodynamic equilibrium is achieved at a constant temperature. However, in the actual cooling-solidification process, the temperature of the molten steel decreases rapidly, and the reaction cannot achieve a full balance. Therefore, it is possible to find only the approximate precipitate types and sequence of inclusions for reducing calcium treatment.

\section{Composition of refining slag}

To improve the castability of molten steel, an effective method is to change the deoxidation products into lowmelting-point inclusions during the tapping process. It is also necessary to control the reaction between the refining slag and molten steel, particularly to inhibit the formation of the high-melting phase in low-alloy steel. Therefore, in order to maintain a low level of high melting-point inclusions and to obtain better fluidity of the molten steel, the final composition of the refining slag needs to be controlled, and excessive slag-steel reaction must be avoided. The appropriate refining slag should be determined using the following principles. It should have an appropriate melting point and viscosity, to better maintain fluidity. The slag is weakly oxidizable, so it does not react easily with the $\mathrm{Al}$ in steel. Thus, the formation of $\mathrm{Al}_{2} \mathrm{O}_{3}$ inclusions is prevented. The slag should have good desulphurization ability. Inclusions in the steel can be assimilated in the low melting-point area and can then be easily absorbed by the slag. It should help prevent lining erosion, and use little fluorite in order to protect the environment.

Because the aluminium activity of the ship plate steel is higher, according to Equation [11] it is relatively easy for the reduction reaction with $\mathrm{SiO}_{2}$ in the slag to occur during the refining process (Huang, 2007; Maeda et al.,1989), thus $\mathrm{Al}_{2} \mathrm{O}_{3}$ system inclusions with a high melting point would be generated.

$$
\mathrm{Al}+0.75\left(\mathrm{SiO}_{2}\right)_{\text {slag }}=0.75 \mathrm{Si}+0.5\left(\mathrm{Al}_{2} \mathrm{O}_{3}\right)_{\text {inc }}
$$

According to the Gibbs free energy isothermal equation, $\Delta G=\Delta G^{\theta}+R T \ln /$, where $\Delta G^{\theta}$ is the Gibbs free energy in the standard state, and $J$ is the activity ratio of the substances under the actual reaction conditions. To suppress the highmelting-point $\mathrm{Al}_{2} \mathrm{O}_{3}$ products when $[\mathrm{Al}]=0.030 \%$, the necessary condition is $a_{\left(\mathrm{Al}_{2} \mathrm{O}_{3}\right)}^{0.5} /, a_{\left(\mathrm{SiO}_{2}\right)}^{0.75}$ therefore improving the $\mathrm{Al}_{2} \mathrm{O}_{3}$ activity or reducing the $\mathrm{SiO}_{2}$ activity in the slag can inhibit the steel-slag reaction. According to the isoactivity phase diagram for $a_{\left(\mathrm{Al}_{2} \mathrm{O}_{3}\right)}$ and $a_{\left(\mathrm{SiO}_{2}\right)}$, the slag compositions that inhibit reaction [11] were identified and are plotted on the phase diagram, as shown in Figure 6.
As can be seen, the refining slag compositions are controlled in the highlighted region when the $\mathrm{Al}_{2} \mathrm{O}_{3}$ content is more than 30 mass \% and the $\mathrm{SiO}_{2}$ content is less than 12 mass \%, which demonstrates the benefits of the inhibiting reaction [11] from a thermodynamic point of view. However, in the actual smelting process, the $\mathrm{SiO}_{2}$ content of the tapped slag is high and the raw slag materials may carry some $\mathrm{SiO}_{2}$ into the ladle. It was therefore decided that the $\mathrm{CaO}-\mathrm{Al}_{2} \mathrm{O}_{3}$ $\mathrm{SiO}_{2}$ system refining slag would be used.

The sulphur content in steel should be stringently controlled to less than 0.012 mass $\%$, and the refining slag must also have a strong desulphurization capability. The desulphurization reaction in which $\mathrm{Al}$ in steel and $\mathrm{CaO}$ act simultaneously (Ghosh, 1989), can be expressed as Equation [12]. To control the sulphur content to less than 0.012 mass \%, the activities must be controlled to is $a_{\left(\mathrm{Al}_{2} \mathrm{O}_{3)}\right.} / a_{(\mathrm{CaO})}^{3}$ $<2.1$, so improving the $\mathrm{CaO}$ activity in the slag can promote the desulphurization reaction. Under controlled conditions, according to the iso-activity phase diagram for $a_{\left(\mathrm{Al}_{2} \mathrm{O}_{3}\right)}$ and $a_{(\mathrm{CaO})}$, the slag components that promote reaction [12] were identified and are plotted on the phase diagram, as can be seen from Figure 7 . The refining slag compositions should be controlled within the range for promoting the reaction: 45-60 mass $\% \mathrm{CaO}, 20-50$ mass $\% \mathrm{Al}_{2} \mathrm{O}_{3}$, and $<25$ mass $\% \mathrm{SiO}_{2}$.

$$
2 \mathrm{Al}+3 \mathrm{~S}+3(\mathrm{CaO})_{\text {slag }}=3(\mathrm{CaS})_{\text {slag }}+\left(\mathrm{Al}_{2} \mathrm{O}_{3}\right)_{\text {slag }}
$$

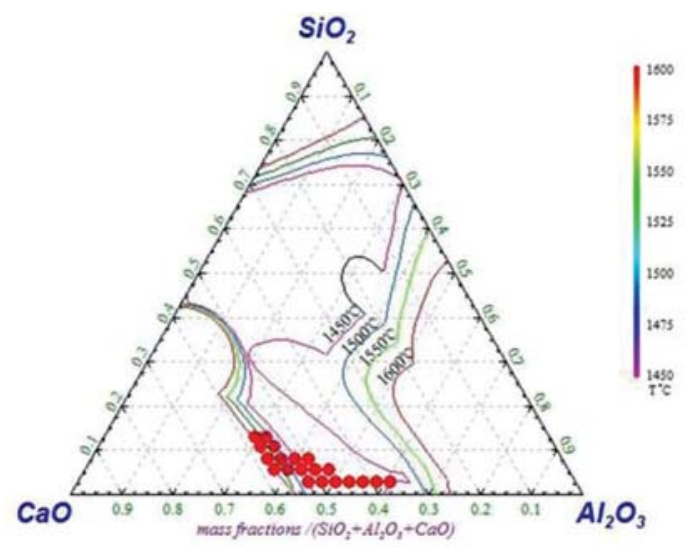

Figure 6-Range of refining slag for inhibiting reaction [11] (red circles)

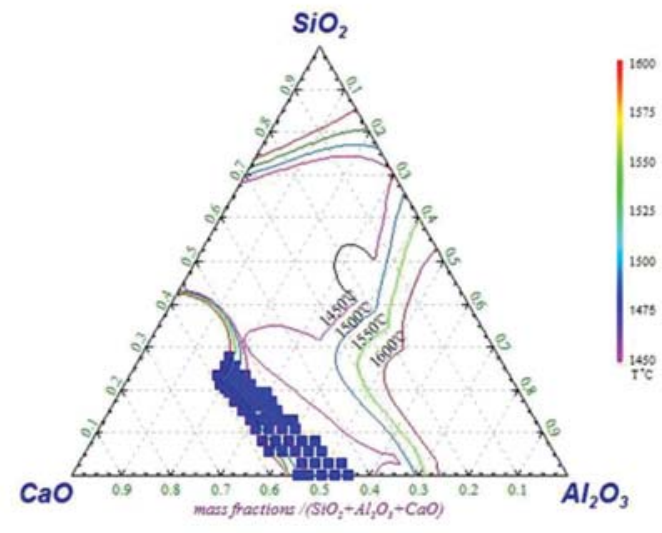

Figure 7-Range of refining slag for promoting reaction [12] (blue circles) 


\section{Control of complex inclusions in high-strength ship plate steel by reducing calcium treatment}

In order to ensure that the inclusions are strongly assimilated and absorbed, the refining slag must also have a lower melting point and viscosity. Furthermore, the liquid region can be expanded by adding about 8 mass $\% \mathrm{MgO}$ to the refining slag (Dong et al., 2014), which plays a role in protecting the lining of the ladle. In order to control the melting point of the refining slag in the liquid phase region below $1500^{\circ} \mathrm{C}$, the $\mathrm{CaO} / \mathrm{Al}_{2} \mathrm{O}_{3}$ mass ratio should not be more than 1.8. With a view of inhibiting the steel-slag reaction, in conjunction with its desulphurization ability, the refining slag composition is ultimately controlled in the liquid region to $45-53$ mass $\% \mathrm{CaO}, 30-37$ mass $\% \mathrm{Al}_{2} \mathrm{O}_{3}$ 6-12 mass $\% \mathrm{SiO}_{2}$, and 6-8 mass \% MgO. This conclusion is related to the formulation of Yoon et al. (2002). When the $\mathrm{CaO}$ content of refining slag was a fixed value, increasing the $\mathrm{Al}_{2} \mathrm{O}_{3}$ content in the slag was conducive to deoxidization.

\section{Industrial application}

\section{Control of T[O] content}

The changes in the $\mathrm{T}[0]$ content in steel at different stations are shown in Figure 8. By optimizing the slag composition and reducing the calcium treatment, the steel cleanliness improved significantly after slag washing. Compared to the previous optimization, the average $\mathrm{T}[0]$ content in CAS (composition adjustment by sealed argon bubbling) was 80 ppm, a decrease of $32 \%, \mathrm{~T}[0]$ removal rate was $58.5 \%$ during LF refining, and the average T[0] content was below $18 \mathrm{ppm}$ in the slab. Although LF treatment time was shorter than in the original process, the quick slagging could extend the slagsteel contact time. This can not only complete the interface reaction, but also reduces the risk of entrapment; and secondary oxidation was successfully prevented in the tundish, so that the oxygen content can be maintained at a lower level.

\section{Control of inclusions in steel}

The morphology and type of major inclusions are listed in Figure 9. Under the original conditions, although a large amount of calcium wire was fed into the molten steel, the yield was particularly low, the micro-inclusions contained a lot of high-melting $\mathrm{Al}_{2} \mathrm{O}_{3}, \mathrm{CaO} \cdot \mathrm{Al}_{2} \mathrm{O}_{3}$, or $\mathrm{CaO} \cdot 2 \mathrm{Al}_{2} \mathrm{O}_{3}$, the actual amount of calcium wire significantly reduced after optimizing the refining process, spherical inclusions were located near $12 \mathrm{CaO} \cdot \mathrm{Al}_{2} \mathrm{O}_{3}$ in the slab, the outer calcium aluminates were enclosed with MnS or CaS, because of the interaction with the furnace lining, top slag, and molten steel, and this led to a certain amount of $\mathrm{MgO}$ in the inclusions.

Before $\mathrm{LF}$ treatment, many $\mathrm{Al}_{2} \mathrm{O}_{3}$ inclusions were observed in the steel, and there was also a small amount of $\mathrm{MnO}-\mathrm{SiO}_{2}-\mathrm{Al}_{2} \mathrm{O}_{3}$. After LF treatment, the typical inclusions changed into spherical $\mathrm{CaO}-\mathrm{Al}_{2} \mathrm{O}_{3}-\mathrm{MgO}-(\mathrm{MnS})$ or $\mathrm{CaO}-\mathrm{Al}_{2} \mathrm{O}_{3}-$ $(\mathrm{CaS})(\leq 10 \mu \mathrm{m})$ in the tundish and slab, most of the $\mathrm{CaO}-$ $\mathrm{Al}_{2} \mathrm{O}_{3}-\mathrm{MgO}$ inclusions were located in the area of $3 \mathrm{CaO} \cdot \mathrm{Al}_{2} \mathrm{O}_{3}$ and $\mathrm{CaO} \cdot \mathrm{Al}_{2} \mathrm{O}_{3}$ in the ternary phase diagram, in which the melting points were lower than $1600^{\circ} \mathrm{C}$ (see Figure 10 ), and there was only a small amount of $\mathrm{CaO}-\mathrm{MgO}$ or $\mathrm{MgO}-\mathrm{Al}_{2} \mathrm{O}_{3}$ inclusions.

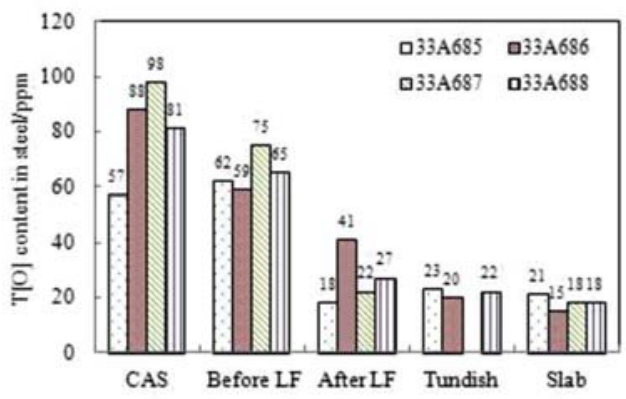

Figure 8-Change of T[O] content in different stations

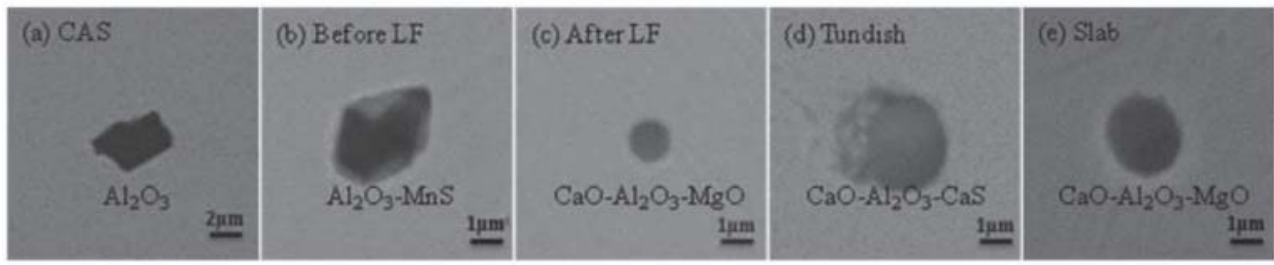

Figure 9-Morphologies of typical inclusions in steel in different stations (a) CAS, (b) before LF, (c) after LF, (d) tundish, (e) slab

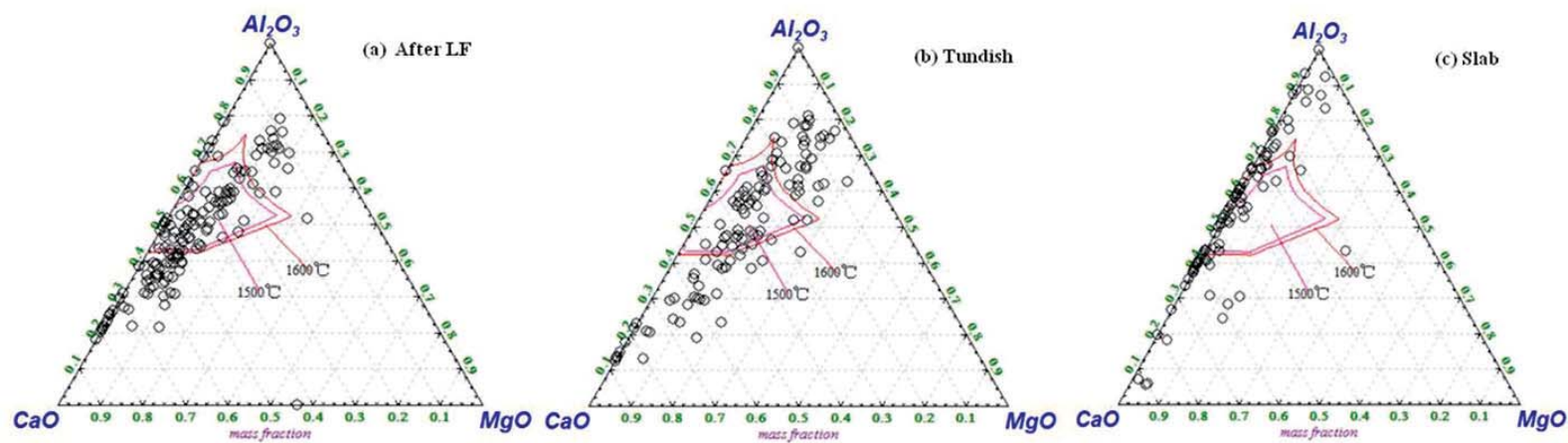

Figure $10-$ Melting points of $\mathrm{CaO}-\mathrm{MgO}-\mathrm{Al}_{2} \mathrm{O}_{3}$ inclusions in each station after optimization (a) after $\mathrm{LF}$, (b) tundish, (c) slab 


\section{Control of complex inclusions in high-strength ship plate steel by reducing calcium treatment}

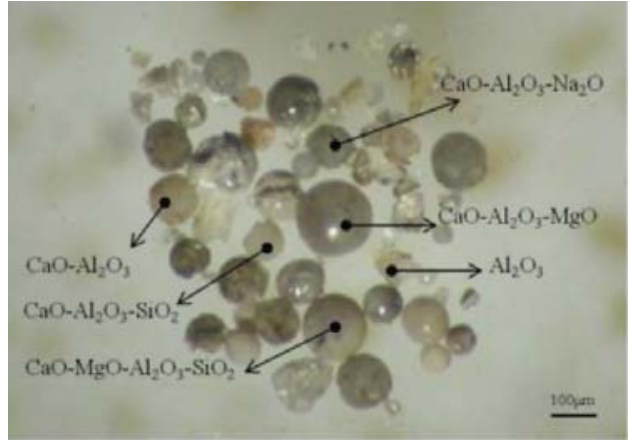

Figure 11-Morphology of macro-inclusions in slab

The amount of electrolysed macro-inclusions was less than $13.9 \mathrm{mg}$ per $10 \mathrm{~kg}$ in the slab. After process optimization, spherical $\mathrm{CaO}-\mathrm{Al}_{2} \mathrm{O}_{3}$ and $\mathrm{CaO}-\mathrm{Al}_{2} \mathrm{O}_{3}-\mathrm{MgO}-$ $\left(\mathrm{SiO}_{2}\right)$ system inclusions were mainly present in the steel, at sizes less than $200 \mu \mathrm{m}$ (Figure 11). Only individual inclusions contained a small amount of $\mathrm{Na}_{2} \mathrm{O}$, which indicated that entrapment does not occur in the mould.

\section{Conclusions}

1. When the contents of $\mathrm{Ca}$ and $\mathrm{Mg}$ in the liquid steel are very low, the inclusions can be controlled in the $1600^{\circ} \mathrm{C}$ liquid region of the $\mathrm{CaO}-\mathrm{Al}_{2} \mathrm{O}_{3}-\mathrm{MgO}$ system. For highstrength ship plate steel, to control the compositions of the $\mathrm{CaO}-\mathrm{MgO}-\mathrm{Al}_{2} \mathrm{O}_{3}$ inclusions in the liquid phase region of $\mathrm{MgO}<10$ mass \%, $\mathrm{Al}_{2} \mathrm{O}_{3} 45-60$ mass \%, $\mathrm{CaO} 40-55$ mass $\%$, when the balanced $\mathrm{Al}$ content is 0.03 mass \%, the $a_{[\mathrm{Ca}]}$ in the liquid steel is $1-10 \mathrm{ppm}$ and $a_{[\mathrm{Mg}]}$ is 0.01 $0.3 \mathrm{ppm}$; when the balanced $\mathrm{Al}$ content is 0.06 mass \%, the $a_{[\mathrm{Ca}]}$ in the liquid steel is $1-30 \mathrm{ppm}$ and $a_{[\mathrm{Mg}]}$ is $0.05-0.9 \mathrm{ppm}$.

2. The $\mathrm{CaO}-\mathrm{Al}_{2} \mathrm{O}_{3}-\mathrm{CaS}$ inclusions can be controlled in the liquid region below $1600^{\circ} \mathrm{C}$, when $a_{\text {[Ca] }}$ in the liquid steel is $5 \mathrm{ppm}, 15 \mathrm{ppm}$, and $30 \mathrm{ppm}$ separately, and the balanced $\mathrm{Al}$ content should be controlled in the range of $0.001-0.050$ mass $\%, 0.005-0.250$ mass $\%$, and 0.01 0.50 mass $\%$. Obviously, with increasing $a_{[\mathrm{Ca}]}$, the $\mathrm{Al}$ content in liquid steel is gradually increased.

3. With a view to controlling the melting point of the refining slag in the liquid phase region below $1500^{\circ} \mathrm{C}$ and inhibiting the steel-slag reaction, in conjunction with its deoxidization and desulphurization ability, the composition range of the refining slag is ultimately controlled in the liquid region, with $45-53$ mass $\% \mathrm{CaO}$, 30-37 mass $\% \mathrm{Al}_{2} \mathrm{O}_{3}, 6-12$ mass $\% \mathrm{SiO}_{2}$, and 6-8 mass \% MgO.

4. The reducing Ca treatment improved the cleanliness of the ship plate steel. Micro-inclusions, with sizes below $10 \mu \mathrm{m}$, are mainly in the $\mathrm{CaO}-\mathrm{Al}_{2} \mathrm{O}_{3}-\mathrm{MgO}$ or the $\mathrm{CaO}-\mathrm{Al}_{2} \mathrm{O}_{3}$ system, with only a small amount of $\mathrm{MgO}-\mathrm{Al}_{2} \mathrm{O}_{3}$, and the $\mathrm{T}[\mathrm{O}]$ content was controlled to $18 \mathrm{ppm}$ or less in the slab.

\section{Acknowledgments}

Project (E2016402096, E2016402111) supported by the Iron and Steel Joint Foundation of Hebei Province; Project supported by the Higher Education Teaching Reform Project of Hebei Province (2017GJJG129) and Fastener Technology Research Institute of Hebei Province.

\section{References}

Chen, J.-X. 1984. Steelmaking Chart and Data Manual, 1th edn. Metallurgical Industry Press, Beijing.

Coletti, B., Vantilt, S., Blanpain, B., and SRidhar, S. 2003. Observation of calcium aluminate inclusions at interfaces between $\mathrm{Ca}$-treated, Al-killed steels and slags. Metallurgical and Materials Transactions B, vol. 34B, no. 5. pp. 533-538.

Dong, Y-W., Jiang, Z.-H., CAO, Y.-L, Zhang, H.-K., and Shen, H.-J. 2014. Effect of $\mathrm{MgO}$ and $\mathrm{SiO}_{2}$ on surface tension of fluoride containing slag. Journal of Central South University, vol. 21, no. 11. pp. 4104-4108.

Funr, F., CicutTI, G., and WALTER, G. 2003. Relationship between nozzle deposits and inclusion composition in the continuous casting of steels. Iron and Steelmaker, vol. 32, no. 12. p. 53.

GeLdenhuis, J.M.A. and Pistorius, P.C. 2000. Minimization of calcium additions to low carbon steel grades. Ironmaking and Steelmaking, vol. 27, no. 6 . pp. 442-449.

GHosh, A. 1989. Secondary Steelmaking: Principles and Applications. CRC Press, Boca Raton, Florida.

HolAPPA, L., LiUKKonEn, H.M., and Lind, M. 2003. Thermodynamic examination of inclusion modification and precipitation from calcium treatment to solidified steel. Ironmaking and Steelmaking, vol. 30, no. 2. pp. 111-115

HuAnG, X-H. 2007. Iron and Steel Metallurgy Principle. 3rd edn. Metallurgical Industry Press, Beijing.

Joo. H.P. 2007. Formation mechanism of spinel-type inclusions in high-alloyed stainless steel melts. Metallurgical and Materials Transactions B, vol. 38, no. 4. pp. 657-663.

KAushiK, P., LEHMANN, J., and NADi,F.M. 2012. State of the art in control of inclusions, their characterization, and future requirements. Metallurgical and Materials Transactions B, vol. 43, no. 4. pp. 710-725.

Maeda, S., Soejima, T., Saito, T., Matsumoto, H., Fujimoto, H., and Mimura, T. 1989. Shape control of inclusions in wire robs for high tensile tire by refining with synthetic slag. Proceedings of the 72nd Steelmaking Conference. Chicago. ISS-AIME, Warrendale, PA. pp. 379-385.

Pretorius, E.B., Oltmann, H.G., and CASH, T. 2009. The effective modification of spinel inclusions by Ca Treatment in LCAK steel. AIST2009 Proceedings. Association for Iron and Steel Technology, St Louis. pp.1035-1049.

Pretorius, E.B., Oltmann, H.G., and CAsh, T. 2009. The effective modification

SEO, W.G., HAN, W.H., KIM, J.S., and PAK, J.J. 2003. Deoxidation equilibria among $\mathrm{Mg}, \mathrm{Al}$ and $\mathrm{O}$ in liquid iron in the presence of $\mathrm{MgO} \cdot \mathrm{Al}_{2} \mathrm{O}_{3}$ spinel. ISIJ International, vol. 43, no. 2. pp. 201-208.

Tоровокі, H. and Mizuno, K. 2004. Effect of silica in slag on inclusion compositions in 304 stainless steel deoxidized with aluminum. ISI) International, vol. 44, no. 8. pp. 1350-1357.

WANG, X-H., LI, H-B., and WANG Y. 2009. Composition change of the nonmetallic inclusions during the secondary refining of low oxygen alloyed structural steels. AIST2009 Proceedings. Association for Iron and Steel Technology, St Louis. pp.965-972.

Xu, K-D. 2009. Certain basic subjects on clean steel. Acta Metallurgica Sinica, vol. 45, no. 3. pp. 257-269.

YANG, J., YAmASAKI, T., and KuWABARA, M. 2007. Behavior of inclusions in deoxidation process of molten steel with in situ produced Mg vapor. ISIJ International, vol. 47, no. 5. pp. 699-708.

YANG, S-F., LI, J.-S., WANG, Z.-F., LI, J., and Lin, L. 2011. Modification of $\mathrm{MgO} \cdot \mathrm{Al} 2 \mathrm{O} 3$ spinel inclusions in Al-killed steel by Ca-treatment. International Journal of Minerals, Metallurgy and Materials, vol. 18, no. 1. pp. 18-23.

Yoon, B.H., HEo, K.H., KIM, J.S., and SoHN, H.S. 2002. Improvement of steel cleanliness by controlling slag composition. Ironmaking and Steelmaking, vol. 29, no. 3. pp. 214-217.

ZhANG, L-F., Aокі, J., and TномAs, B.G. 2006. Inclusion removal by bubble flotation in a continuous casting mold. Metallurgical and Materials Transactions B, vol. 37B, no.5. pp. 361-379.

Zhao, S., WAng, Q., Xu, J.-F, Peng, M-M., and He, S-P. 2013. Control on melting temperature of $\mathrm{CaO}-\mathrm{Al}_{2} \mathrm{O}_{3}-\mathrm{SiO}_{2}-\mathrm{MgO}$ inclusions in low carbon low alloy steel. Journal of Central South University (Science and Technology), vol. 44, no. 8. pp. 3121-3128. 